\title{
MODERATING EFFECT OF TECHNOLOGY ON THE RELATIONSHIP BETWEEN CHANGE MANAGEMENT AND PERFORMANCE OF COMPANIES LISTED IN NAIROBI SECURITIES EXCHANGE IN KENYA
}

\author{
Aketch E. Ng'ong'a, PhD \\ Business Strategy Consultant, Kenya \\ Leon Awiti, PhD \\ Data Scientist, United States of America \\ Richard M.Imbambi, PhD \\ Lecturer, Kenya \\ Wycliffe Mande \\ Human Resource, Research and Learning Practitioner, Kenya \\ Vincent N.Machuki, PhD \\ Director and Senior Lecturer, Kenya \\ http://doi.org/10.35409/IJBMER.2020.3183
}

\begin{abstract}
The study examined the moderating effect of technology on the relationship between change management and performance of companies listed in NSE in Kenya. A cross sectional survey design was used for 64 companies listed in the NSE in Kenya. The sample size was 38 companies from (2013-2017) as at 30th June, 2017. Purposive sampling technique for 4 senior managers namely, Chief Executive Officers, divisional heads in Human Resource, Finance and Marketing from the listed companies in NSE were targeted with a sample size of 152 managers. Pilot study was conducted on 15 respondents and reliability coefficient(r) and was above the recommended threshold of 0.7.The study used five point Likert Scale Secondary data was obtained from published sources and primary data from the semi-structured questionnaire. The analysis comprised descriptive statistics, Pearson's correlation, hypotheses testing and regression analysis using ANOVA. The composite mean $=3.83$ this meant that technology played a considerable role in the relationship between change management and performance, F-statistic value was 148.439 with p-value $0.000<0.05$ and the null hypothesis was rejected. The study concluded that technology significantly moderated the relationship between change management and performance of companies listed in NSE. The study recommends that the management of companies listed in NSE should upscale the usage of technology in their business processes /operations and further studies may also re-look at other moderating or mediating variables.
\end{abstract}

Keyword: Change Management, Technology, Performance of Companies, Nairobi Securities Exchange (NSE), Capital Markets Authority (CMA).

\section{INTRODUCTION}

Technology has been a driving force in change management and performance of companies listed in the stock market. Manufacturing firms in U.S. and Europe had returns from IT 


\section{International Journal of Business Management and Economic Review}

Vol. 3, No. 04; 2020

ISSN: 2581-4664

investment lower than expected because of manager's inability to effectively align IT investments with organization's strategy (Loveman, 1994). In Kenya, the introduction of ATM, online banking has been well embraced by customers transacting without visiting the bank (Iraya \& Saiti, 2018). Companies need to exploit different levels of electronic integration, based on data consistency and system integration to gain desired levels of control, coordination and learning among their channel partners (Jean, Sinkovics \& Kim, 2008). Creation of IT systems in capital markets makes work simpler in accomplishing goals of the organization with internet trading development and reassuring investors about their safety and property information (Abdi, Faghani \& Tabatabaee,2013).The increasing global competition, technological change and expansion of customer expectations are creating turbulent competitive environment for organizations to be competitive (Khatoon \& Farooq, 2016).

In Australia, change and change management both at federal and state level reflected a sense of urgency for the government to revitalize the public service in order to sustain continuity and change (D'Ortenzio, 2012). Suresh (2011) defines change management as a method of empowering organizations and individuals for taking over their responsibility. Whereas, Aljohani (2016) defines change management as a "set of aptitudes and skills an individual is required for successful initiation and implementation of change in creation of value for the organization". D'Ortenzio (2012) noted that organizations must realize that it is important to have an integrated approach to any change program that involves combining structural, technological and behavioral approaches. Victor \& Franckeiss (2002) argued that organizational change needs to focus on developing strategy through to operational implementation and evaluation. Grimsley (2013) defined technology as "the making, modification, usage and knowledge of tools, machines, techniques, systems and methods of organization in order to solve a problem, improve a pre-existing solution to a problem or achieve a goal." Burns \& Mohapatra (2008) argued that automation leads to reduced human resource related costs since fewer people are required to operate the systems as opposed to them carrying out the actual process.

Simons (2000) opined that corporate performance is an approach of market mechanism by which the company actively interacts with the financial factor and customer product markets. Kaplan and Norton (1992) argued that the extended measurement of corporate performance is by balanced scorecard. Net profit (profit for the year) refers to the profit made by the business for the year may be calculated before or after the subtraction of taxation (Tulsian, 2014). Corporate dividend policy refers to determining the amount to be paid to the shareholders (Ross, Westerfield and Jaffe, 2005). Return on investment (ROI) refers to the measure of profitability which is expressed in percentage (Best, 2009; Drury, 2007; Moutinho and Southern, 2010). Gaye (2017) stated that the performance of Kenyan economy grew steadily at an average rate of 5\% per year with the exception of 2017 where it grew by 4.7\%. The GDP growth of 5.7\% in 2015, $5.9 \%$ in 2016 and $4.9 \%$ in 2017. The GDP in agriculture was (24.2\%), industry (14.8\%), services $(62.5 \%)$ in 2015 (Gaye, 2017). The performance indicated that there was a decline of $1 \%$ between 2016 and 2017 GDP growth rate (Gaye, 2017). Capital Markets Authority and Nairobi Securities Exchange being regulatory bodies have an obligation to ensure that listed companies comply and operate according to the set down standards when trading in the securities exchange (CMA, 2002; NSE, 2013). The financial statements on performance of listed companies are shared with 


\section{International Journal of Business Management and Economic Review}

Vol. 3, No. 04; 2020

ISSN: 2581-4664

these regulatory bodies, investors and the public to ensure that there is an element of transparency (NSE, 2014). The study looked at the moderating effect of technology on the relationship between change management and performance of companies listed in NSE in Kenya.

\section{Statement of the Problem}

In Kenya, organizations have not adopted appropriate technology fully as an accompanying component in managing change in the prevailing turbulent and disruptive age to gain a competitive edge to survive; most companies have not appreciated the role of technology in this process. Often, companies perceive technological innovation as a stand-alone driver of organizational performance. Nohria \& Beer (2000) observed that about $70 \%$ of all change initiatives fail. Abbas et al. (2014) study focused on the effect of information technology on performance of allied bank employees in Pakistan. Njoroge, Muathe \& Bula (2016) study focused on the effect of technology on performance of mobile telephone industry in Kenya. Consumers on the hand, have become more demanding and technology is transforming operations/processes which require organizations to manage change properly to overcome resistance to change and be competitive. The researchers didn't come across any study that looked at the moderating effect of technology on the relationship between change management and performance of companies listed in NSE in Kenya.

\section{Research Objective}

To establish the moderating effect of technology on the relationship between change management and performance of companies listed in NSE.

\section{Research Hypothesis}

$\mathrm{H}_{0}$ : Moderating effect of technology does not significantly affect the relationship between change management and performance of companies listed in NSE.

\section{LITERATURE REVIEW}

\section{Theoretical Framework}

\section{The Three Step Change Theory}

The theory of change was propounded by Lewin (1951) and looked at change in a three step model of unfreezing, moving and refreezing. Lewin conceived the three-step model in analyzing, understanding and bringing about planned change at the group, organizational and societal levels. The first step was unfreezing, which means that human behavior was based on a quasistationery equilibrium supported by a complex field force. Before old behavior could be discarded (unlearnt) and new behavior successfully adopted, the equilibrium needed to be destabilized (unfrozen) (Burnes, 2004). The second step was moving, that meant taking into consideration all the operating forces, identifying and evaluating iteratively the available options.

Whereas, the third step was refreezing, that meant to stabilize the group at a new semi- stationary balance that would ensure that new practices were relatively safe from regression. The new behavior must be, to some degree, congruent with the rest of the behavior, personality and 


\section{International Journal of Business Management and Economic Review}

Vol. 3, No. 04; 2020

ISSN: 2581-4664

environment of the learner or it would simply lead to a new round of disconfirmation (Schein, 1996). Refreezing were those change processes in organizational culture, norms, policies and practices which the organization is undertaking during change process (Burnes, 2004). Lewin's model does not explicitly state the notion that simply introducing change would result in the change being adopted or being sustained over the long run. When you create change and it fails, it means that there is a problem in one of the three steps in the model. Lewin's planned change approach is still very relevant globally (Burnes, 2004). However, the three step theory informed the variable/concept of change management in this study.

\section{Technology Organization Environment Model}

Technology Organization Environment Model was propounded by Tornatzky \& Fleischer (1990) focuses on internal and external factors affecting the adoption of an innovation and concluded that diffusion of an innovation is influenced by technology, organization and environmental factors. Their framework identified the factors which influenced the process of adoption, implementation and uses of technological innovations. In their conclusion, they reported that technological factors included the existing technologies in use and new technologies relevant to the firm. Organizational factors namely descriptive measure includes scope, size and the amount of slack resources available internally. The environmental factors include where the firm conducts its business namely, industry, competitors and dealings with the government (Tornatzky \& Fleischer, 1990).

According to Rogers (2003) innovation is an idea, practice or object that is perceived as new by an individual or another unit of adoption. Diffusion is a way of communicating a new creation/innovation to the members of a social system (Rogers, 2003). Agarwal (2000) argued that the theory of innovation diffusion comprises potential users who make decisions to adopt or reject an innovation based on their beliefs regarding innovation. It has five characteristics namely; relative advantage, compatibility, complexity, trialability and observability. Firstly, relative advantage refers to an innovation as better than the idea it replaced. Secondly, compatibility refers to consistency of innovation and has potential end-users existing values, prior experiences and needs. Thirdly, complexity refers to end-users perceived level of difficulty in understanding innovations and their ease of use. Fourthly, trialability refers to the extent by which innovations are tested on a limited basis. Lastly, observability refers to the visibility of innovation results by other people. Lee, Hsieh \& Hsu (2011) indicates that these characteristics explain the end-user having a new creation and making decision for it. However, the technology organization environment model informed the variable/concept of technology in this study.

\section{Industrial Organization Economics Theory}

This was propounded by Bain (1968) and focused on the experience of industrialized nations (Basu, 1993). The field of industrial organization had been transformed during the past twenty years and that game theory had emerged as a predominant methodology for analyzing business strategy (Shapiro, 1989). This means that the new industrial organization involves specifying a game among competing firms and solving that game in extensive form using the non-cooperative solution concept of Nash equilibrium or one of its refinements. Fisher (1989) argued that game theoretic approach to industrial organization had been unsuccessful. The sensitivity of equilibrium behavior had evidence that the game theoretic approach had failed since the 


\section{International Journal of Business Management and Economic Review}

Vol. 3, No. 04; 2020

ISSN: 2581-4664

specification may be hard to discern from available industry information.

According to Porter (1981) the traditional brain/mason paradigm of industrial organization offered strategic management a systematic model for assessing competition within an industry, yet the model was seldom used in the business policy field. Industrial organization and business policy differed in their frame of reference (public vs. private), units of analysis (industry vs. firm), views of the decision maker and stability of structure and in other significant respects. Porter (1981) concluded that the development of industrial organization theory during the 1970's had indicated that the industrial organization should be resourceful to policy scholars. However, Industrial organizational Economics Theory informed the variable/concept of performance of companies in this study.

\section{Empirical Literature Review}

\section{Change Management and Performance of Companies Listed NSE}

A number of researches have been done on change management and organization performance for example; Olajide (2014) conducted a study on change management and organizational performance of Nigerian telecoms industries of Airtel Nigeria and reported that change in technology, customer taste and leadership had a significant effect on performance. The study concentrated on change management dimensions such as organizational structure, change in technology and individuals on performance and did not consider organizational culture, organizational strategy, organizational structure and organizational management and did not show how the moderating effect of technology relates to organizational performance. The study did not consider other public companies and different sectors of the economy in the Kenyan context. Wanza \& Nkuraru (2016) studied the influence of change management and employee performance at the University of Eldoret in Kenya. Their study found that change management factors such as leadership, culture, structure and technology influenced employees' performance at all levels positively in the university. The 4 variables were all independent variables and failed to bring out the technology as a moderating variable in the relationship between change management and performance of companies. The study was conducted in an educational institution of higher learning but this study was on listed public companies in NSE in Kenya.

Ndahiro, Shukla \& Oduor (2015) conducted a study on the effect of change management and performance of government institutions in Rwanda Revenue Authority (RRA), Rwanda and focused on planned change and implementation. Their study failed to bring out the contribution done by organizational culture, strategy, structure and management when moderated by technology on performance of companies. The study was done in Rwanda and not in a Securities Exchange in the Kenyan context. Jaradat et.al, (2013) conducted a research on the impact of change management and performance of employees in the university libraries in Jordan. They found that there was a positive relationship between change in organizational structure, technology, individuals and performance. The study failed to address how the moderating effect of technology contributes to organizational performance and further failed to include organizational culture, strategy and management. Jaradat et.al, (2013) study was conducted in an educational institution of higher learning in Jordan and not in a public company in the Kenyan 


\section{International Journal of Business Management and Economic Review}

Vol. 3, No. 04; 2020

ISSN: 2581-4664

context.

Nyaungwa, Linganiso \& Karodia (2015) conducted a study on assessing the impact of change management and performance of Zimra region in Zimbabwe. They found out that team work, communication, staff involvement and commitment lacked during change process which resulted to resistance to change. Nyaungwa, Linganiso \& Karodia (2015) recommended that Zimra should establish a plan to communicate and involve staff in the organization to reduce resistance to change by conducting training. And that same research should be conducted in other regions in Zimra to see how change was managed in those regions and tax administration with similar changes should be conducted in other countries. Nyaungwa, Linganiso \& Karodia (2015) study did not consider dimensions of change management namely, organizational culture, strategy, structure and management on performance of companies. Their target population consisted of 410 employees and no distinction was made in their designation whether they were all managers or not. The study concentrated on regions within Zimbabwe and did not consider companies in different sectors of the economy that are in the Securities Exchange in the Kenyan context.

Change management and organizational performance has been studied widely on case studies bases in developed and developing countries but the inclusion of technology as a driving force in the business environment within the industry has been missing for its role. The variables for this study include organizational culture, strategy, structure and management which show that there has not been a consensus on getting an absolute and agreeable road map to unpack this concept of moderating effect of technology on the relationship between change management and performance of companies listed in NSE in Kenya. It is on this breath that this study intends to address the gaps that have been identified from these studies in the Kenyan context.

\section{Technology and Performance of Companies listed in NSE}

Nwosu, Awurum \& Okoli (2015) study on evaluation of the effect of technological innovations on corporate performance of selected manufacturing firms in Nigeria Stock Exchange reported that process innovation, product innovation, organizational structure and employee development had a significant positive effect on the performance. The target population was 8725 from ten manufacturing firms. The sample size used a structured questionnaire. The study used descriptive survey design while t-statistics was adopted for hypotheses testing. The study concluded that the firms attested to the presence of technological innovation as a critical success factor and recommended that employee development facilitates technological innovation and firms should adopt appropriate structure as it provides a solid foundation for the operation of companies and technology. The study concentrated on manufacturing firms in Nigeria Stock Exchange and left out some sectors of the economy. The study did not consider indicators such as technology innovation, technology adoption and technology diffusion which this study intends to address.

In another study by Reichert \& Zawislak (2014) on technological capability and firm performance on Brazilian firms of low and medium-low technology industries. They reported that firms of lower technological intensity industries performed above average in the economic performance indicators since they invested below average in technological capability. Their study was based on economic development theory with a target population of 133 Brazilian 


\section{International Journal of Business Management and Economic Review}

Vol. 3, No. 04; 2020

ISSN: 2581-4664

firms. The study reported failure to confirm the existence of a positive relation between technological capability and firm performance because there were other elements that allowed firms to achieve such results. They used secondary data from companies' annual reports and profit and loss statements and websites. The period covered was from the years 2008 to 2010 . Data collection procedure was a documentary research. The sample size was smaller thirty eight with a low rate. The data was not representative enough to warrant generalization of the results. The study did not collect data from primary sources and the companies were not large to trade in the stock exchange. This study did not consider technology indicators such as technology innovation, technology adoption and technology diffusion which this study intends to address.

A study by Richards, Yeoh, Chong \& Popovič (2014) on an empirical study of business intelligence impact on corporate performance management reported the effectiveness of the related planning and analytic practices. Richards et al., (2014) further reported that size and industry sector do not influence the relationships between business intelligence effectiveness and the corporate performance management. The study conducted a survey to collect data from 337 senior managers. Partial least square method was employed to analyze the data. The study did not link the variable of technology indicators such as technology innovation, technology adoption and technology diffusion which this study intends to address in the Kenyan context.

Mazidi, Amini \& Latifi (2014) conducted a study on the impact of information technology capability and firm performance; a case of employee-customer profit chain at technical and vocational organization in Mashhad city in Iran. Their study reported that there was a strong support for the structural equation modeling. Mazidi, Amini \& Latifi (2014) study used a questionnaire and quantitative data collected from a sample of 212 employees. They recommended that future research may investigate a direct linkage between information technology capability and employee customer profit chain elements in other organizational contexts such as business organizations and manufacturing or replace a more effective construct to formulate this effect. The study failed to make causal conclusions and some of the relationships could be inflated or deflated because of the cross-sectional survey adopted in the study. The generalization of results could not apply to service organizations and educational institutions. Mazidi, Amini \& Latifi (2014 study did not link the variable of technology indicators such as technology innovation, technology adoption and technology diffusion that are critical which this study intends to address in the Kenyan context.

\section{Performance of Companies listed in NSE}

Santos \& Brito (2012) conducted a study toward a subjective measurement model for firm performance and reported that dimensions cannot be used interchangeably because they represent different aspects of firm performance and that stakeholders also have different interests that need to be managed independently. Their study used confirmatory factor analyses data from 116 Brazilian senior managers to test its fit and psychometric properties. Santos \& Brito (2012) study lacked convenience and geographic characteristics of the sample to allow generalization of the results and also failed to test the dimension of market value. The final model had six first order dimensions: profitability, growth, customer satisfaction, employee satisfaction, social performance, and environmental performance. A second-order financial performance construct, 


\section{International Journal of Business Management and Economic Review}

Vol. 3, No. 04; 2020

ISSN: 2581-4664

influencing growth and profitability, correlated with the first-order inter correlated, non-financial dimensions. They recommended that researchers and practitioners may use the model to fully treat performance in empirical studies and to understand the impact of strategies on multiple performance facets.

Another study by Fauzi, Svensson \& Rahman (2010) reviewed corporate performance, corporate financial performance and corporate social performance. They reported that the concept of triple bottom line as sustainable corporate performance should consist of three measurement elements namely; (i) financial, (ii) social and (iii) environmental. The content of each of these measurement elements may vary across contexts and over time and they should be interpreted to be a relative concept that is dynamic and iterative. They recommended that continuous monitoring need to be performed, adapting the content of the measurement elements to changes that evolve across contexts and over time in the marketplace and society. Kabajeh, Nu'aimat \& Dahmash (2012) study examined ROA, ROE and ROI ratios together and separately with Jordanian insurance public companies share prices during the period (2002-2007). They reported that there was a positive relationship between ROA, ROE, ROI ratios and Jordanian insurance public companies share prices. Their findings further showed a positive but low relationship between each of ROA ratio and ROI ratio separately and Jordanian insurance public companies share prices. Their study was based on the empirical evidence. Kabajeh, Nu'aimat \& Dahmash (2012) concluded that there was no relationship between the ROE ratio and Jordanian insurance public companies market share prices.

\section{Conceptual Framework}

This study was guided by the following conceptual framework:

Independent Variable Moderating Variable

Change Management
- Organizational Culture
- Organizational Strategy
- Organizational Structure
Organizational Management

Figure 1: Conceptual Framework

\section{RESEARCH METHODOLOGY}

The study adopted a cross sectional survey which was considered to be appropriate for its

Dependable Variable

\section{Performance of Companies}

Listed in NSE

Financial

- Net Profit

- Dividend Per Share

- Return on Investment

Non-Financial

\section{Technology}

- Technology Innovation

- Technology Adoption

- Technology Diffusion
- Quality Products and Services

- New Products

- Customer Satisfaction 


\section{International Journal of Business Management and Economic Review}

Vol. 3, No. 04; 2020

ISSN: 2581-4664

purpose, scope, researcher involvement and time period over which the data was collected: nature of the data, type of analysis and at a specific time. A correlation research design was also considered because this study involved quantitative and testing of the hypothesis. Scholars such as (Machuki \& K'Obonyo, 2011; Irungu, 2007) used this design to test hypotheses and their conclusions were widely accepted. The cross-sectional survey design was appropriate in this study because the researcher collected descriptive data that was handled statistically which allowed for hypothesis testing in order to come up with objective conclusions.

The target population of the study was 164 companies drawn from public companies listed in Nairobi Securities Exchange. A sample of 38 companies listed in NSE formed the unit of analysis and a purposive sample that included; chief executive officers, heads of human resources, finance and marketing who participated in the study totaling to 152 senior managers. Cronbach's Alpha was used after collecting the data from the pilot study to measure the common internal consistency and stability of the multiple Likert questions in the survey/questionnaire that formed a scale to determine the reliability. Walker (1997) opined that pilot studies help to clarify research question boundaries and make the research more focused. The questionnaire was piloted with companies not included in the study. This was totaling to $10 \%$ of 152 respondents which equals to 15 senior managers according to Mugenda \& Mugenda (2003) who suggested a range of $10 \%-30 \%$ to be representative, reliability and flexibility. The sample size was determined based on precision rate and confidence level. A desired minimum precision rate of $+5 \%$ and a confidence level of $95 \%$ was used (Kothari, 2009).

Pearson's coefficient of correlation denoted by (r) was used to analyze the data. Analysis of variance (ANOVA) and F-test was used to study the amount of variations within the sample before conducting regression analysis. The statistical package for social sciences (SPSS) version 17.0 and Microsoft excel was used in the data analysis. In addition, data from SPSS output was presented using tables, charts, bar graphs, and graphs for results of statistical analysis. Cochran's formula of 'return sample size method' for categorical data as propounded by Mugenda and Mugenda (2003).The formula was found to be effective in determining the sample size by Kinyua (2016).

Formula:

$$
z^{2} p(1-p)
$$

Where: $\quad n-$ is the desired sample size.

$z$ - is the corresponding standard score with probability of error at 0.05 and a confidence level of $95 \%$ that is 1.96 .

$p$ - is the occurrence level of phenomenon under study and is equal to 0.5 where the occurrence level is unknown.

$d$ - is the selected probability of error in the study corresponding with $95 \%$ confidence level that is 0.1 . 
International Journal of Business Management and Economic Review

Vol. 3, No. 04; 2020

ISSN: 2581-4664

\section{RESULTS AND DISCUSSION}

\section{Technology, Change management and Performance of Companies listed in NSE}

The study sought to establish moderating effect of technology on the relationship between change management and performance of companies listed in NSE. The respondents were asked to state their level of agreement/disagreement with the following items based on technology and how they are associated with Performance of Companies listed in Nairobi Securities Exchange in a Likert Scale of 1-5, where:1-strongly disagree, 2-strongly agree, 3-neutral, 4-agree and 5strongly agree. The results are presented in table 1.

Table 1: Descriptive Statistics for Technology

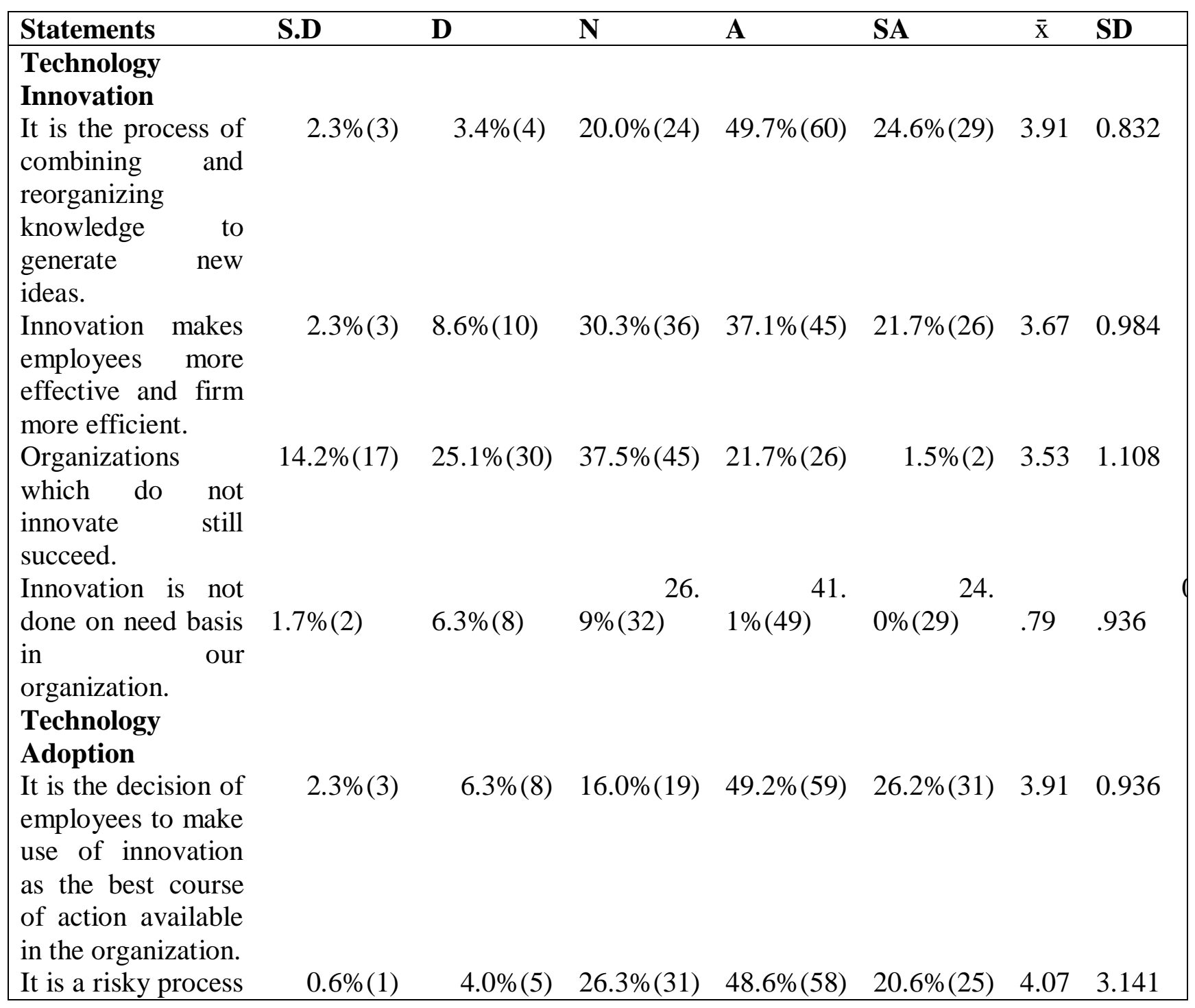




\section{International Journal of Business Management and Economic Review}

Vol. 3, No. 04; 2020

ISSN: 2581-4664



Table 1 findings on whether technology is the process of combining and reorganizing knowledge to generate new ideas, 2.3\%(3) of the respondents strongly disagreed, 3.4\%(4) disagreed, 


\section{International Journal of Business Management and Economic Review}

Vol. 3, No. 04; 2020

ISSN: 2581-4664

$20.0 \%$ (24) were neutral, 49.7\%(60) of the respondents agreed and 24.6\%(29) strongly agreed. An average score rate of 3.91 was recorded with standard deviation of 0.832 which is above the composite mean of 3.83. This indicates that majority of organizations consider technology as a process of combining and reorganizing knowledge to generate new ideas which positively affect performance of companies listed in NSE.

On whether innovation makes employees more effective and firm more efficient, 2.3\%(3) strongly disagreed, $8.6 \%(10)$ disagreed, while $30.3 \%(36)$ were neutral, $37.1 \%(45)$ of the respondents agreed, $21.7 \%(26)$ strongly agreed. An average score rate of 3.67 was recorded with standard deviation of 0.984 which is below the composite mean of 3.83 and overall standard deviation of 1.035. This suggests that innovation negatively affect performance of companies listed in NSE.

On whether organizations which do not innovate still succeeds,13.1\%(17) strongly disagreed, $25.1 \%$ (30) disagreed, while $36.6 \%$ (45) were neutral, 20.0\%(26) of respondents agreed, $1.7 \%(2)$ strongly agreed. Average scale of 3.53 out possible 5 and standard deviation of 1.108 was recorded which is below the composite mean of 3.83 and overall standard deviation of 1.035. This means that the organizations which do not innovate negatively affects performance of companies listed in NSE.

To find out whether innovation is not done on need basis for many organization listed in Nairobi Securities Exchange in Kenya, 1.7\%(2) strongly disagreed, 6.3\%(8) disagreed, while 26.9\%(32) were neutral, majority at $41.1 \%$ (49) of respondents agreed, $24.0 \%(29)$ strongly agreed. Average score rate was 3.79 out of 5 and standard deviation of 0.936 was below the composite mean of 3.83 and overall standard deviation of 1.035. This indicates that innovation that is not done on need basis negatively affect performance of companies listed in NSE.

Based on whether decision of employees to make use of innovation is the best course of action available in the organization; the finding suggests that; $2.3 \%$ (3) strongly disagreed. , $6.3 \%$ ( 8) disagreed, while $16.0 \%$ ( 19) of respondent were neutral, 49.1\%( 59) of respondent agreed, 26.3 $\%$ ( 31) of respondent strongly agreed. Average score rate was 3.91 out of 5 with standard deviation of 0.936 was higher than the composite mean of 3.83 and overall standard deviation of 1.035. This indicates that employees' feedbacks is very important and are in agreement hence, behaves wisely and honestly for implementation of technology adoption as they are the users and this positively affect performance of companies listed in NSE.

On whether it is a risky process that any slight mistake in transferring cash is not reversible through electronic funds transfer; $0.6 \%(1)$ strongly disagreed, $4.0 \%(5)$ disagreed, while 26.3 $\%(31)$ of respondent were neutral, $48.6 \%(58)$ of respondent agreed, $20.6 \%(25)$ of respondent strongly agreed. Average score rate was 4.07 out of 5 with standard deviation of 3.141 was higher than the composite mean of 3.83 and overall standard deviation of 1.035.This indicates that electronic funds transfer can be challenging especially, when a wrong button is pressed creates a loss to the organizations which negatively affect performance of companies listed in NSE. 


\section{International Journal of Business Management and Economic Review}

Vol. 3, No. 04; 2020

ISSN: 2581-4664

On whether the processes have been made user friendly in the organization; $0.6 \%$ (1) strongly disagreed, 7.4\%(9) disagreed, while 16.0\%(19) of respondent were neutral, $50.9 \%(61)$ of respondent agreed, 25.1\%(30) of respondent strongly agreed. Average score rate was 3.93 out of 5 with standard deviation of 0.871 was higher than the composite mean of 3.83 and overall standard deviation of 1.035. This indicates that the processes and usage of technology by employees positively affect performance of companies listed in NSE.

On whether it does not lessen the volume of work within the organization, $1.7 \%(2)$ strongly disagreed, $12.1 \%(15)$ disagreed, while $28.7 \%(34)$ of respondent were neutral, $37.4 \%(45)$ of respondent agreed, $20.1 \%(24)$ of respondent strongly agreed. Average score rate was 3.62 out of 5 with standard deviation of 0.994 was below the composite mean of 3.83 and overall standard deviation of 1.035 . This indicates that volume of work done digitally by employees negatively affect performance of companies listed in NSE.

On whether our organization does not accept new ideas and products easily from the market; 1.7 $\%$ ( 2) strongly disagreed. , $9.1 \%$ ( 11) disagreed, while $22.3 \%$ (27) of respondent were neutral, $37.7 \%$ (45) of respondent agreed, $29.1 \%$ (35) of respondent strongly agreed. Average score rate was 3.83 out of 5 with standard deviation of 1.006 was at par with the composite mean of 3.83 and overall standard deviation of 1.035 .

On whether it offers awareness building and technology demonstration, 4.0\%(5) strongly disagreed, $15.4 \%$ (18) disagreed, while $25.1 \%(30)$ of respondent were neutral, $41.1 \%(50)$ of respondent agreed, $14.3 \%(17)$ of respondent strongly agreed. Average score rate was 3.46 out of 5 with standard deviation of 1.044 was below the composite mean of 3.83 and overall standard deviation of 1.035. This indicates that awareness and technology demonstration negatively affect performance of companies listed in NSE.

On whether on the job training, management seminars and team building are conducted to enlighten staff on technology, 0.0\%(0) strongly disagreed, 2.9\%(3) disagreed, while 22.9\%(28) of respondent were neutral, 52.6\%(63) of respondent agreed, 21.7\%(26) of respondent strongly agreed. Average score rate was 3.93 out of 5 with standard deviation of 0.704 was higher than the composite mean of 3.83 and overall standard deviation of 1.035. This indicates that staff trainings, seminars and team building that organizations conduct brings awareness to employees and positively affect performance of companies listed in NSE.

On whether a network of trained staff offers technological advice to the organization, $1.7 \%(2)$ strongly disagreed, 5.7\%(7) disagreed, while 26.3\%(32) of respondent were neutral, 46.9\%(56) of respondent agreed, 19.4\%(23) of respondent strongly agreed. Average score rate was 3.77 out of 5 with standard deviation of 0.77 was below the composite mean of 3.83 and overall standard deviation of 1.035. This indicates that information technology support staff are available to offer advice on need basis which negatively affect performance of companies listed in NSE. The summary is presented in table 2 . 
International Journal of Business Management and Economic Review

Vol. 3, No. 04; 2020

ISSN: 2581-4664

Table 2: Summary of Descriptive Statistics for Technology

\begin{tabular}{|llll|}
\hline Technology & Mean & Std. Deviation & Analysis N \\
\hline Technology Innovation & 3.703 & 0.993 & 120 \\
Technology Adoption & 3.855 & 1.316 & 120 \\
Technology Diffusion & 3.782 & 0.879 & 120 \\
\hline
\end{tabular}

Table 2 show that for technology was noted at an average score rate of 3.703, 3.855 and 3.782 out of 5 for technology innovation, adoption and diffusion and SP4 was recorded with standard deviation of $0.993,1.316$ and 0.879 respectively. The findings suggest that technology innovation, adoption and diffusion had a significant effect on performance of companies listed in NSE.

The results are in harmony with findings by Nwosu, Awurum and Okoli (2015) that process innovation, product innovation, organizational structure and employee development had a significant positive effect on the performance. The results also agree with the findings of Richards, Yeoh, Chong \& Popovič (2014) that the more effective the business intelligence implementation, the more effective the corporate performance management related planning and analytic practices.

The results also concur with the findings of Mazidi, Amini \& Latifi (2014) that there was a strong support for the structural equation modeling between information technology capability and service process innovation. The results show that most of the companies listed in NSE in Kenya are practicing technological innovation that has made their employees more effective and efficient.

The results further confirms that the technological innovation, adoption and diffusion cuts across companies listed in NSE with a network of trained staff who offer technological advice. The result show that companies navigate the evolving technological landscape by identifying their short and long term technological needs to better performance. The findings also were in approval of technology organization environment model propounded by Tornatzky and Fleischer (1990) in this study.

\section{Correlation Analysis for Technology, Change Management and Performance of Companies listed in NSE}

Correlation analysis gives the relationship between variables. In this study, Pearson product moment correlation coefficient ( $r$ 's) was used to establish the relationship between the independent variables without moderator technology. The correlation coefficients are summarized in Table 3 and 4. 
International Journal of Business Management and Economic Review

Vol. 3, No. 04; 2020

ISSN: 2581-4664

Table 3: Correlation Analysis of Independent Variables without Moderator Technology

\begin{tabular}{|c|c|c|c|c|c|}
\hline Variables & & \multirow{2}{*}{$\begin{array}{l}\text { Organizatio } \\
\text { nal Culture } \\
1\end{array}$} & \multirow{2}{*}{$\begin{array}{l}\begin{array}{l}\text { Organizatio } \\
\text { nal Strategy }\end{array} \\
.578^{* *}\end{array}$} & \multirow{2}{*}{$\begin{array}{l}\begin{array}{l}\text { Organizatio } \\
\text { nal } \\
\text { Structure }\end{array} \\
.667^{* *}\end{array}$} & \multirow{2}{*}{$\begin{array}{l}\text { Organizati } \\
\text { onal } \\
\text { Manageme } \\
\text { nt } \\
.526^{* *}\end{array}$} \\
\hline Organizational & $\begin{array}{l}\text { Pearson } \\
\text { Correlation }\end{array}$ & & & & \\
\hline Culture & Sig. (2-tailed) & & .000 & .000 & .000 \\
\hline & $\mathrm{N}$ & 120 & 120 & 120 & 120 \\
\hline & Pearson & $.578^{* *}$ & 1 & $.696^{* *}$ & $.666^{* *}$ \\
\hline $\begin{array}{l}\text { Organizational } \\
\text { Strategy }\end{array}$ & $\begin{array}{l}\text { Correlation } \\
\text { Sig. (2-tailed) }\end{array}$ & .000 & & .000 & 000 \\
\hline & $\mathrm{N}$ & 120 & 120 & 120 & 120 \\
\hline Organizational & $\begin{array}{l}\text { Pearson } \\
\text { Correlation }\end{array}$ & $.667^{* *}$ & $.696^{* *}$ & 1 & $.682^{* *}$ \\
\hline Structure & $\begin{array}{l}\text { Sig. (2-tailed) } \\
\mathrm{N}\end{array}$ & $\begin{array}{l}.000 \\
120 \\
526^{* *}\end{array}$ & $\begin{array}{l}.000 \\
120 \\
666^{* *}\end{array}$ & 120 & $\begin{array}{l}.000 \\
120\end{array}$ \\
\hline Organizational & $\begin{array}{l}\text { Pearson } \\
\text { Correlation }\end{array}$ & $.526^{* *}$ & $.666^{* *}$ & $.682^{* *}$ & 1 \\
\hline Management & $\begin{array}{l}\text { Sig. (2-tailed) } \\
\mathrm{N}\end{array}$ & $\begin{array}{l}.000 \\
120\end{array}$ & $\begin{array}{l}.000 \\
120\end{array}$ & $\begin{array}{l}.000 \\
120\end{array}$ & 120 \\
\hline
\end{tabular}

Table 3 findings also reveals that there was a significant relationship between the independent variables since all the p-values were less than 0.01 that is, p- values $0.000<0.01$. Even though there was a significant effect between the independent variables, there was no problem of multicollinearity among the variables since all the $\mathrm{r}$ values were less than 0.8 as suggested by Tabachnick and Fidel (2001). The correlation coefficients are summarized in Table 4.

Table 4: Correlation Analysis of Independent Variables with Moderator Technology

\begin{tabular}{|c|c|c|c|c|c|}
\hline Variables & & $\begin{array}{l}\text { Organizatio } \\
\text { nal Culture }\end{array}$ & $\begin{array}{l}\text { Organizatio } \\
\text { nal Strategy }\end{array}$ & $\begin{array}{l}\text { Organizatio } \\
\text { nal } \\
\text { Structure }\end{array}$ & $\begin{array}{l}\text { Organizati } \\
\text { onal } \\
\text { Manageme } \\
\text { nt }\end{array}$ \\
\hline Organizational & $\begin{array}{l}\text { Pearson } \\
\text { Correlation }\end{array}$ & 1 & $.499^{* *}$ & $.695^{* *}$ & $.414^{* *}$ \\
\hline Culture & Sig. (2-tailed) & & .000 & .000 & .000 \\
\hline & $\mathrm{N}$ & 120 & 120 & 120 & 120 \\
\hline Organizational & $\begin{array}{l}\text { Pearson } \\
\text { Correlation }\end{array}$ & $.499^{* *}$ & 1 & $.440^{* *}$ & $.878^{* *}$ \\
\hline Strategy & Sig. (2-tailed) & .000 & & .000 & .000 \\
\hline
\end{tabular}




\section{International Journal of Business Management and Economic Review}

Vol. 3, No. 04; 2020

ISSN: 2581-4664

\begin{tabular}{|llllll|}
\hline \hline & $\mathrm{N}$ & 120 & 120 & 120 & 120 \\
& Pearson & $.695^{* *}$ & $.440^{* * *}$ & 1 & $.436^{* *}$ \\
Organizational & Correlation & & & & \\
Structure & Sig. (2-tailed) & .000 & .000 & & .000 \\
& $\mathrm{~N}$ & 120 & 120 & 120 & 120 \\
& Pearson & $.414^{* *}$ & $.878^{* *}$ & $.436^{* *}$ & 1 \\
Organizational & Correlation & & & & \\
Management & Sig. (2-tailed) & .000 & .000 & .000 & 120 \\
& $\mathrm{~N}$ & 120 & 120 & 120 & 120 \\
\hline **. Correlation is significant at the 0.01 level (2-tailed). & & \\
\hline
\end{tabular}

Table 4, the presence of moderator (Technology), correlation coefficient $r$ values were above 0.8 and the relationship among the independent variable was significant. Since the $r$ values were above 0.8. Tabachnick \& Fidel (2001) rule of thumb was contradicted hence probably there was a problem of multicollinearity, this therefore, suggests that the model was good enough in the absence of moderator.

Hypothesis testing for moderating effect of technology on the relationship between change management and performance of companies listed in NSE

The study analyzed the null hypothesis that the moderating effect of technology does not significantly affect the relationship between change management and performance of companies listed in NSE. The findings indicate that the overall model was satisfactory as it was supported by coefficient of determination also known as the R-square of 0.646 . This means that all the independent variables explain $64.6 \%$ of the variations in the dependent variable. In addition to that, the model improved in the presence of moderator as the overall R- square increased from 0.646 to 0.811 that is from $64.6 \%$ to $81.1 \%$. The results of ANOVA for technology, change management and performance of companies listed in NSE are presented in Table 5.

Table 5: Analysis of Variance (ANOVA) with moderator and without moderator

\begin{tabular}{|lllllll|}
\hline Model & & Sum of Squares & Df & Mean Square & F & Sig. \\
\hline & Regression & 12.723 & 4 & 3.181 & 62.938 & $.000^{\mathrm{b}}$ \\
1 & Residual & 6.974 & 138 & .051 & & \\
& Total & 19.697 & 142 & & & \\
2 & Regression & 54.321 & 4 & 13.580 & 148.439 & $.000^{\mathrm{b}}$ \\
& Residual & 12.625 & 138 & .091 & & \\
& Total & 66.947 & 142 & & & \\
\hline $\begin{array}{l}\text { a. Dependent Variable: Performance of Companies } \\
\text { b. Predictors: (Constant), Organizational }\end{array}$ \\
Structure, Organizational Management:
\end{tabular}

Table 5 indicates that the overall model was statistically significant. This was supported by an F statistic of 62.938 and the reported $\mathrm{p}$-value $<0.001$ which was less than the conventional 


\section{International Journal of Business Management and Economic Review}

Vol. 3, No. 04; 2020

ISSN: 2581-4664

probability of 0.05 significance level. Also for model 2 where the moderator is present the model was still significant as the $\mathrm{F}$ statistic value was 148.439 with $\mathrm{p}$-value $0.000<0.05$. These results suggest that the independent variables are good predictors of performance of companies listed in NSE in both absence and presence of moderator. The study therefore, rejects the null hypothesis that the moderating effect of technology does not significantly affect the relationship between change management and performance of companies listed in NSE. The study accepts the alternative hypothesis that the moderating effect of technology significantly affect the relationship between change management and performance of companies listed in NSE.

\section{Multivariate Regression Analysis for Technology, Change Management and Performance of Companies Listed in NSE}

The section presents the results to establish the moderating effect of technology in the relationship between change management and performance of companies listed in NSE. Change management was the independent variables such as organizational culture, strategy, structure, management and performance of companies (dependent variable) listed in NSE and moderated with technology. A multiple linear regression model was used to test the significant effect of the independent variables on the dependent variable. Therefore, the overall model for the study was;

$$
\mathrm{Y}_{\mathrm{t}}=\beta_{0}+\beta_{1} \mathrm{X}_{1 \mathrm{t}}+\beta_{2} \mathrm{X}_{2 \mathrm{t}}+\beta_{3} \mathrm{X}_{3 \mathrm{t}}+\beta_{4} \mathrm{X}_{4 \mathrm{t}}+e_{\mathrm{t}},
$$

Where:

$$
\begin{aligned}
& \mathrm{t}=\text { Period } 2013 \text { to } 2017 \\
& \mathrm{Yt}=\text { Performance of Companies } \\
& \mathrm{X}_{1 \mathrm{t}}=\text { Organizational Culture } \\
& \mathrm{X}_{2 \mathrm{t}}=\text { Organizational Strategy } \\
& \mathrm{X}_{3 \mathrm{t}}=\text { Organizational Structure } \\
& \mathrm{X}_{4 \mathrm{t}}=\text { Organizational Management }
\end{aligned}
$$

\begin{tabular}{|c|c|c|c|c|c|c|c|}
\hline \multirow[t]{2}{*}{ Model } & \multicolumn{2}{|c|}{$\begin{array}{l}\text { Unstandardized } \\
\text { Coefficients }\end{array}$} & \multirow{2}{*}{$\begin{array}{l}\text { Standardize } \\
\text { d } \\
\text { Coefficients } \\
\text { Beta }\end{array}$} & \multirow[t]{2}{*}{$\mathbf{t}$} & \multirow[t]{2}{*}{ Sig. } & \multicolumn{2}{|l|}{$\begin{array}{l}\text { Collinearity } \\
\text { Statistics }\end{array}$} \\
\hline & B & $\begin{array}{l}\text { Std. } \\
\text { Error }\end{array}$ & & & & Tolerance & VIF \\
\hline $\begin{array}{l}\text { Model 1 } \\
\text { (Constant) }\end{array}$ & $\overline{1.965}$ & .180 & & 10.919 & .000 & & \\
\hline $\mathrm{X}_{1}$ & .166 & .057 & .204 & 2.930 & .004 & .528 & 1.892 \\
\hline $\mathrm{X}_{2}$ & .277 & .063 & .339 & 4.400 & .000 & .433 & 2.309 \\
\hline $\mathrm{X}_{3}$ & .194 & .060 & .272 & 3.226 & .002 & .361 & 2.772 \\
\hline $\mathrm{X} 4$ & .074 & .048 & .116 & 1.554 & .022 & .463 & 2.161 \\
\hline
\end{tabular}

The analyses of the fitness of the model used in the study are presented in Table 6 .

Table 6: Coefficients for Overall Regression 


\section{International Journal of Business Management and Economic Review}

Vol. 3, No. 04; 2020

ISSN: 2581-4664

\begin{tabular}{|llllllll}
\hline \hline Model 2 & -1.871 & .242 & & -7.724 & .000 & & \\
(Constant) & & & & & & & \\
$\mathrm{X}_{1} \mathrm{~T}$ & .232 & .076 & .154 & 3.035 & .003 & .528 & 1.892 \\
$\mathrm{X}_{2} \mathrm{~T}$ & .380 & .085 & .252 & 4.482 & .000 & .433 & 2.309 \\
$\mathrm{X}_{3} \mathrm{~T}$ & .274 & .081 & .208 & 3.385 & .001 & .361 & 2.772 \\
$\mathrm{X}_{4} \mathrm{~T}$ & .509 & .064 & .429 & 7.902 & .000 & .463 & 2.161 \\
\hline
\end{tabular}

Table 6 shows that there was a positive significant effect between performance of companies listed in NSE and organizational culture, strategy, structure and management. From the findings, the overall model 1 obtained was expressed as:

$$
\mathrm{Y}_{\mathrm{t}}=1.965+0.166 \mathrm{X}_{1 \mathrm{t}}+0.277 \mathrm{X}_{2 \mathrm{t}}+0.194 \mathrm{X}_{3 \mathrm{t}}+0.074 \mathrm{X}_{4 \mathrm{t}}
$$

The regression model was written as: performance of the company $=1.965+0.166$ organizational culture +0.277 organizational strategy +0.194 organizational structure +0.074 organizational management. They were supported by beta coefficients of $0.166,0.277,0.194$ and 0.074 respectively. The findings were statistically significant with p-values less than 0.05 for all the variables tested. The result indicate that a change in either of the variables will lead to a positive change in performance of companies listed in NSE.

$\mathrm{Yt}=$ Performance of the company

$\mathrm{t}=$ Period 2013 to 2017

$\mathrm{X}_{1 \mathrm{t}}=0.166$; indicates that a unit change in organizational culture resulted into 0.166 change in performance of the company.

$\mathrm{X}_{2 \mathrm{t}}=0.277$; shows that a unit change in organizational strategy resulted into 0.277 change in performance of the company.

$\mathrm{X}_{3 \mathrm{t}}=0.194$; indicates that a unit change in organizational structure resulted into 0.194 change in performance of the company.

$\mathrm{X}_{4 \mathrm{t}}=0.074$; implied that a unit change in organizational management resulted into 0.074 change in performance of the company.

Besides that, in the presence of moderator $\mathrm{T}$ (Technology) in model 2 becomes:

$$
\mathrm{Y}_{\mathrm{t}}=-1.871+0.232 \mathrm{X}_{1} \mathrm{~T}_{\mathrm{t}}+0.380 \mathrm{X}_{2 \mathrm{t}} \mathrm{T}_{\mathrm{t}}+0.274 \mathrm{X}_{3 \mathrm{t}} \mathrm{T}_{\mathrm{t}}+0.509 \mathrm{X}_{4 \mathrm{t}} \mathrm{T}_{\mathrm{t}}
$$

The regression model was written as: performance of the company $=1.871+0.232$ organizational culture +0.380 organizational strategy +0.274 organizational structure +0.509 organizational management.

$\mathrm{Yt}=$ Performance of the company

$\mathrm{t}=$ Period 2013 to 2017

$\mathrm{X}_{1 \mathrm{t}}=0.232$; shows that a unit change in organizational culture resulted into 0.232 change in performance of the company.

$\mathrm{X}_{2 \mathrm{t}}=0.380$; implied that a unit change in organizational strategy resulted into 0.380 change in performance of the company.

$X_{3 t}=0.274$; shows that a unit change in organizational structure resulted into 0.274 change in 


\section{International Journal of Business Management and Economic Review}

Vol. 3, No. 04; 2020

ISSN: 2581-4664

performance of the company.

$\mathrm{X}_{4 \mathrm{t}}=0.509$; indicates that a unit change in organizational management resulted into 0.509 change in performance of the company.

$\mathrm{Tt}=\mathrm{Technology}$

These were supported by beta coefficients of $0.232,0.380,0.274$ and 0.509 respectively. The findings were statistically significant with p-values which was 0.05 for all the variables tested. It was therefore, concluded from the analysis that the null hypothesis be rejected and the alternative be accepted that there was a positive significant moderating effect of technology in the relationship between change management and performance of companies listed in NSE.

\section{CONCLUSION AND RECOMMENDATIONS \\ Conclusion}

It was inferred that technology significantly moderated the relationship between change management and performance of companies listed in NSE.

\section{Recommendation}

The management of companies listed in NSE should upscale the usage of technology in their business processes /operations as one of the key drivers of change management towards efficiency, effectiveness and performance in the dynamic competitive business environment. This will help them realign according to the changing business environment. Management should ensure that they invest more in automation so that they do not become obsolete but be current and relevant.

\section{REFERENCES}

Abbah, M.T. (2014). Employee Motivation: The Key to Effective Organizational Management in Nigeria. IOSR Journal of Business and Management, 16 (4), 01-08.

Abdi, H.R.D., Faghani, F. and Tabatabaee, S.M. (2013). Impact of Information Technology Development on Stock Market development. Empirical Study in the World's Leading Capital Markets. International Journal of Academic Research in Accounting, Finance and Management Sciences, 3(1), 382-390.

Agarwal, V. (2000). Multi-Period Performance Persistence Analysis of Hedge Funds. Journal of Financial and Quantitative Analysis, 35(3), 327-342.

Basu, K. (1993). Lectures in Industrial Organization Theory, Oxford: Basil Blackwell.

Bain, J.S. (1968). Barriers to New Competition, Cambridge, Mass.: Harvard University Press.

Best, R. J. (2009). Market-Based Management: Strategies for Growing Customer Value and Profitability. ( $5^{\text {th }}$ Ed.), Upper Saddle River, NJ: Pearson Prentice Hall.

Beshtawi, M. \& Jaaron, A. (2014).Change Management in Telecommunications Sector: Managerial Framework. Review of Contemporary Business Research, 3(1), 127-141.

Burnes, B. (2004). Kurt Lewis and Complexity Theories: back to the future? Journal of Change Management, 4(4), 309-325.

Burns, A. and Mohapatra, S. (2008). International Migration and Technological Progress. 


\section{International Journal of Business Management and Economic Review}

Vol. 3, No. 04; 2020

ISSN: 2581-4664

Migration and Development Brief, 4, 1-6, World Bank, Washington, DC.

CMA (2002). The Capital Markets (Licensing Requirements) (General) Regulations.

Nairobi: Capital Markets Authority.

D’Ortenzio, C. (2012). Understanding Change and Change Management Processes: A

Case Study. Unpublished Thesis: University of Canberra.

Drury, C. (2007). Management and Cost Accounting, $\left(7^{\text {th }}\right.$ Ed.), London: Cengage.

Fisher, F. (1989). Games Economists Play: A Non Cooperative View. RAND Journal of

Economics, 19,113-124.

Fauzi, H., Svensson, G. \& Rahman, A.A. (2010). Triple Bottom Line as Sustainable Corporate Performance: A Preposition for the Future. Sustainability, 2(5),

1345-1360.

Gaye, D. (2017).World Bank's Kenya Economic Update: Kenya's Economic Outlook to

Dip In 2017.

Grimsley, S. (2003). Technological Factors in Business: Definition \& Concept, Retrieved from http:/study.com/academy/lesson/technological-factors-in-Shawn-

Business-Definition-lesson-quiz.html.

Irungu, S.M. (2007). The Effects of Top Management Teams on the Performance of Publicly Quoted Companies in Kenya. Unpublished Thesis. Nairobi:

University of Nairobi.

Iraya, C. and Saiti, K. (2018). The Effect of Investment in Technology on Lagged Sto

Returns of Banks Listed at the Nairobi Securities Exchange. International

Journal of Humanities and Social Science, 8 (5), 137-143.

Jean, R.B., Sinkovics, R.R. and Kim, D. (2008). Information Technology and

Organizational Performance within International Business to Business

Relationships. A Review and an Integrated Conceptual Framework. International Marketing Review, 25(5), 563-583.

Jaradat, O., Nagresh, M., Shegran, A., \& Jadellah, N. (2013). Impact of Change Management on the Performance of Employees in University Libraries in Jordan. European Journal of Business and Management, 5(2), 169-178.

Kabajeh, M.A.M. \& Dahmash, F.N. (2012). The Relationship between the ROA, ROE And ROI Ratios with Jordanian Insurance Public Companies Market Share Prices. International Journal of Humanities and Social Science, 2(11), 115-120.

Kaplan, R.S. \& Norton, D.P. (1992). The Balance Scorecard: Measures that Drive Performance. Harvard Business Review, 70(1), 71-80.

Kothari, C.R. (2009). Research Methodology: Methods and Techniques. New Delhi: New Age International.

Lee, Y.H., Hsieh, Y.C. \& Hsu, C.N. (2011). Adding Innovation Diffusion Theory to theTechnology Acceptance Model: Supporting Employees' Intentions to use E-Learning Systems. Educational Technology \& Society, 14 (4), 124-137.

Lewin, K. (1947). Frontiers in Group Dynamics in: D. Cartwright (Ed.) (1952). Field Theory in the Social Science. London: Science Paperbacks.

Loveman, G. W. (1994). "An Assessment of the Productivity Impact on Information

Technologies," in Information Technology and the Corporation of the $1990 s, 1{ }^{\text {st }}$ Ed., T. J. Allen and M. S. Scott (Eds). Cambridge, USA: MIT Press, 1994, pp. 17-78. 


\section{International Journal of Business Management and Economic Review}

Vol. 3, No. 04; 2020

ISSN: 2581-4664

Mazidi, R.K., Amini, A. \& Latifi, M. (2014).The Impact of Information Technology Capability on Firm Performance: a Focus on Employee-Customer Profit Chain. Iranian Journal of Management Studies, 7(1), 95-120.

Machuki, V.M. \& K'Obonyo, P.O. (2011). Organizational Strategic Behavior and Performance of Publicly Quoted Companies in Kenya. Business

Administration and Management, 1(7), 219-232.

Machuki, V.M. (2011). External Environment-Strategy Co-Alignment, Firm-Level Institutions and Performance of Publicly Quoted Companies in Kenya. Unpublished Thesis. Nairobi: University of Nairobi.

Mugenda, O.M. \& Mugenda, A.G. (2003). Research Methods, Quantitative and Qualitative Approaches. African Centre for Technology Studies. Nairobi: Press.

Moutinho, L. \& Southern, G. (2010). Strategic Marketing Management. Andover: Cengage.

NSE Handbook (2013). Corporate Information and Financial Review of Listed EquityCompanies, Nairobi.

NSE Handbook (2014). Prospectus for Admission for Listing and Offer Subscription. July 9, 2014.

NSE Handbook (2016). Corporate Information and Financial Review of Listed EquityCompanies, Nairobi.

Nyaungwa, C., Linganiso, X. \& Karodia, A.M. (2015). Assessing the Impact of Change

Management on the Performance of Zimra Region in Zimbabwe. Kuwait Chapter of Arabian Journal of Business and Management Review, 4(6),76-104.

Nohria, N. \& Beer, M. (2000).Cracking the Code of Change. Harvard Business Review, 1-10.

Ndahiro, S., Shukla, J. \& Oduor, J. (2015). Effects of Change Management on the Performance of Government Institutions in Rwanda, a Case of Rwanda Revenue Authority. International Journal of Business and Management Review, 3(5), 94-107.

Nwosu, H.E., Awurum, J. I., \& Okoli, I.E. (2015). An Evaluation of the Effect of Technological Innovations on Corporate Performance: A Study of

Selected Manufacturing Firms in Nigeria. The International Journal of Business and Management, 3(1), 248-262.

Olajide, O.T. (2014). Change Management and its Effects on Organizational Performance of Nigerian Telecoms Industries: Empirical Insight from Airtel Nigeria.

International Journal of Humanities Social Sciences and Education, 1(11),170-179.

Porter, M.E. (1981). The Contributions of Industrial Organization to Strategic Management. Academy of Management Review, 6(4), 609-620.

Reichert, F.M. \& Zawislak, P.A. (2014). Technological Capability and Firm Performance.Journal of Technology Management \& Innovation, 9(4), 20-25.

Ross, S.A., Westerfield, R. W. \& Jaffe, J. (2005). Corporate Finance, ( $7^{\text {th }}$ Ed.), U.S.A.:McGraw Hill.

Richards, R., Yeoh, W., Chong, A.Y.L. \& Popovič, A. (2014). An Empirical Study of Business Intelligence Impact on Corporate Performance Management. PACIS Proceedings, from: http://aisel.aisnet.org/pacis2014/341.

Rogers, E.M. (2003). Diffusion of innovations. New York: Free Press.

Santos, J.B., \& Brito, L.A. (2012). Toward a Subjective Measurement Model for Firm Performance. BAR Rio de Janeiro, 9(6), 95-117. 


\section{International Journal of Business Management and Economic Review}

Vol. 3, No. 04; 2020

ISSN: 2581-4664

Schein, E.H (1996). "Kurt Lewin's Change Theory in the Field and in the Classroom: Notes toward a Model of Management Learning Systems Practice,9(1), 27-47.

Simons, R. (2000). Performance Measurement and Control System for implementingStrategy, Text and Cases. New York: Prentice Hall.

Shapiro, C. (1989). The Theory of Business Strategy. RAND Journal of Economics,20(1), 127137.

Suresh, H. (2011). Change Management -Must for Todays Organization. Think Business Network Articles, 1-11.

Tabachnick, B.G. \& Fidell, L.S. (2001). Using Multivariate Statistics. New York: Harper\& Row Publishers.

Tulsian, M. (2014). Profitability Analysis: A comparative Study of SAIL \& TATA Steel. Journal of Economics and Finance, 3(2), 19-22.

Tornatzky, L.G. and Fleischer, M. (1990). The Processes of Technological Innovation. Lexington: Lexington Books.

Victor, P. \& Franceiss, A. (2002). 'The Five Dimensions of Change: An Integrated Approach to Strategic Organizational Change Management'. Strategic Change, 11(1), 35-42.

Wanza, L. S. \& Nkuraru, J.K. (2016). Influence of Change Management on Employee Performance: A Case of University of Eldoret. International Journal of Business and Social Science, 7(4), 190-199.

Walker, D.H.T. (1997). Choosing an Appropriate Research Methodology. ConstructionManagement and Economics Journal, 15(2), 149-159. 